\title{
DA ZAMACUECA À CUECA SOLA: SUJEITOS POLÍTICOS NA CULTURA POPULAR LATINO- AMERICANA
}

\section{DANILO MATAVELI}

RESUM 0: Tradicionalmente dançada por um casal (pareja) - uma de suas marcas mais tradicionais - , a cueca é um estilo de música e dança que se tornou uma das forças poéticas mais populares no Chile. Expressão folclórica cujas origens remontam ao século XVIII, a cueca também se caracteriza por ser uma manifestação cultural tipicamente ligada ao campesinato. Este trabalho apresenta uma breve história da cueca, com foco em suas principais variações históricas e nas interpretações políticas e sociais. 0 objetivo é analisar o aspecto político dessa manifestação popular e a relevância do seu caráter poético como modo de organização coletiva de sujeitos políticos. 0 argumento central do trabalho se baseia na noção de que a cueca possui, como muitas outras manifestações da cultura popular, uma energia caótica e um carácter disruptivo cuja apreensão pelo poder nem sempre pode ser realizada de maneira pacífica ou completa.

PALAVRAS-ChAVE: Cultura popular hispano-mericana; Dança chilena e política; $\mathrm{Cu}$ eca; Zamacueca.

O primeiro registro da palavra zamacueca no Dicionário da Língua Castelhana da Real Academia Espanhola foi feito em 1899. Ali, a zamacueca se refereia a uma "danza grotesca que se usa en Chile, en Perú y otras partes de América, comúnmente entre indios, zambos y chuchumecos. // Música y canto con que se baila" (GARRIDO, 1979, p. 16). Em 1976, o musicólogo chileno, Pablo Garrido, 
publica, pela Editorial Nascimento, de Santiago de Chile, um livro chamado Biografia de la cueca, no qual, logo de saída, insurge-se contra esse primeiro registro da zamacueca. Segundo Garrido, a consideração da zamacueca como uma dança grotesca revelava desconhecimento da função de um bem cultural e uma categórica negação de vínculo por parte de Espanha em relação a sua antiga colônia (Idem, pp. 19-22). "Al detractar en tal forma la danza popular," escreve Garrido, "la Academia de la Lengua alejaba - quizás impensadamente - cualquier entroncamiento con las danzas, músicas y poesías peninsulares" (Ibidem, p. 21). A intenção de Garrido é comprovar e celebrar o prestígio da cueca como um bem comum e uma dança nacional, o que passa por um esforço de negação dos atributos destacados pelos colonizadores. "La zamacueca no es una danza grotesca", ele escreve, "y si en sus insondables orígenes tuvo expresiones corporales extravagantes, a fines del siglo pasado no restaba el menor asomo de ello; por el contrario, es un baile gallardo y garboso donde campea la gracia” (Idem, p. 20).

Com "expressões corporais extravagantes", talvez Garrido quisesse se referir aos movimentos pélvicos característicos das danças de matriz africana, mas esse dado não será negado apenas por ser "grotesco" ou inapropriado com relação aos "bons costumes de um povo civilizado, ele será negado por se tratar de um traço étnico cujo apagamento pode ser considerado positivo, já que, sem ele, a cueca deixa de ser extravagante e grosseira para se tornar graciosa. A partir daí, Garrido empreende uma série de argumentos que caminham no sentido de uma verdadeira limpeza étnica. Se, no final do século XIX, o dicionário dizia que a zamacueca era comum entre índios, zambos e chuchumecos, é preciso mostrar que ele estava errado.

Segundo Garrido, os índios chilenos não dançavam zamacueca, porque ela ainda não existia tal como a conhecemos, e, quando ela começou a se esboçar como um costume em América, os índios chilenos já não eram índios, eram “[...] mestizos seculares, con sangre peninsular [...]” (Ibidem, p. 20). Se na Bolívia ou no Peru os índios dançam zamacueca, isso não a torna uma dança de índios, porque eles têm "[...] otras danzas ancestrales que amam mayormente y que sienten mejor" (Ibidem, p. 20). Quanto ao zambo, se ele dança cueca, é porque a Espanha trouxe para as Américas outro fator étnico: "el negro africano, el que al mezclarse con la hembra aborigen dio el zambo, o sea el hijo del negro e india, o al contrario" 
(Ibidem, p. 20-21). Para arrematar, Garrido diz que, se a descrição correspondesse às características reais da cueca, ninguém imaginaria que ela pudesse ser uma "dança nacional”, cultivada por diversos povos latino-americanos (Idem, p. 21).

Essas proposições iniciais de Pablo Garrido a respeito da cueca têm um fundamento histórico e um fundamento político. O fundamento político pode ser considerado identificando um esforço em ressaltar a cueca como um símbolo nacional, uma tradição especificamente chilena. Como símbolo nacional, ela deveria ser valorizada em face de qualquer depreciação, sobretudo daquelas vindas do colonizador. O fundamento histórico diz respeito ao fato de que a zamacueca passou, como muitos outros costumes latino-americanos, por um processo de apagamento de suas origens africanas, indígenas e mestiças, justamente para serem aceitas e assimiladas como expressões de uma nacionalidade essencial para o conceito de soberania de uma nação e de um povo autêntico e homogêneo. Em outras palavras, a invenção da tradição da cueca como processo de criação de símbolos nacionais foi também um processo de domesticação e pacificação das tensões étnicas e culturais que estão na base de sua formação como um costume latino-americano. 35

As definições posteriores da zamacueca e da cueca encontradas no Dicionário da Língua Castelhana da Real Academia Espanhola acompanharam esse processo histórico de limpeza étnica. Garrido se refere à definição presente na $15^{\mathrm{a}}$ edição do dicionário, vigente em 1925 e mantida até a 19ª edição, vigente em 1970: "Zamacueca. f. Baile popular originario del Perú, y que se usa también en Chile y otras partes de América Meridional. // 2. Música y canto de este baile” (Idem, p. 22). Aqui, o índio, o zambo e o chuchumeco desapareceram, assim como a qualificação de “dança grotesca”, substituída por "baile popular”. Esta mudança na definição do dicionário da Real Academia Espanhola estaria mais de acordo com as proposições de Garrido, mas é precisamente ela que comprova o processo histórico de eliminação dos componentes étnicos e o processo de invenção de uma tradição para propósitos sociopolíticos.

35 Os termos "tradição inventada" e "costume" são considerados aqui segundo as proposições de Eric Hobsbawm. (Cf. HOBSBAWM, Eric e RANGER, Terence (orgs.). A invenção das tradições. Rio de Janeiro: Paz e Terra, 1984, pp. 9-23). 
Por fim, o que sobra desta definição é o traço regionalista de uma dança e canto tradicionais, populares, mas sem agentes, pronta para a repetição ritualística e para o consumo de todos os indivíduos e classes sociais. Esta definição se torna ainda mais técnica na presente edição, a 23a , impressa em 2014 e vigente ainda em 2019: "Cueca: 1. f. Baile de América del Sur, desde Colombia hasta la Argentina, Chile y Bolivia, en el que los bailarines, que llevan un pañuelo en la mano derecha, trazan figuras circulares, con vueltas y medias vueltas, interrumpidas por diversos floreos" (RAE, 2019). É interessante notar, nesta última definição, a ausência do adjetivo "popular”, que demonstra o prestígio adquirido pela cueca mesmo entre os membros de uma elite social, tal como descrito e defendido por Garrido em sua Biografia de la cueca, onde lemos que a dança está presente até mesmo nos salões de festas dos mais altos governantes do Chile.

Existe ainda outro fator de ordem política a ser considerado nesse processo de institucionalização e limpeza étnica da zamacueca. Um fator tão relevante quanto o apagamento dos agentes culturais formadores de um costume. Quem olha atentamente para a primeira definição da zamacueca reconhece um verdadeiro documento histórico da utilização da língua como um instrumento de poder. Nesse caso, o dicionário e a língua são postos a serviço de um poder colonizador que qualifica como "grotesca" a expressão do costume de povos sobre os quais deve-se exercer um domínio ético e sociocultural. Para além disso, é possível notar nessa definição o exercício reativo do poder. Diante da potência de uma manifestação cultural indígena, africana e mestiça, Espanha se viu obrigada a incluir no dicionário da sua língua oficial uma definição para ela, mas não sem reagir à possível ameaça que era a resistência do índio, do africano e do mestiço por meio de seus costumes, crenças e divertimentos. Para Espanha, essa resistência era "grotesca".

Ainda no século XIX, outra forma de poder era exercida sobre os costumes latino-americanos: o trabalho intensivo de pintores viajantes europeus como André August Bonnaffé e até mesmo de nativos como o peruano Pancho Fierro. Nessa altura, havia um forte interesse pela documentação etnográfica por parte desses artistas; contudo, pode-se dizer que o seu interesse maior era a exploração de um capital cultural latino-americano por meio da representação iconográfica dos tipos e costumes particulares dessa região (RIVIALE, 2011). A zamacueca foi 
um tema recorrente em aquarelas e litografias que rodavam o mundo, contribuindo para a construção de um imaginário exótico e pitoresco acerca do continente sul-americano.

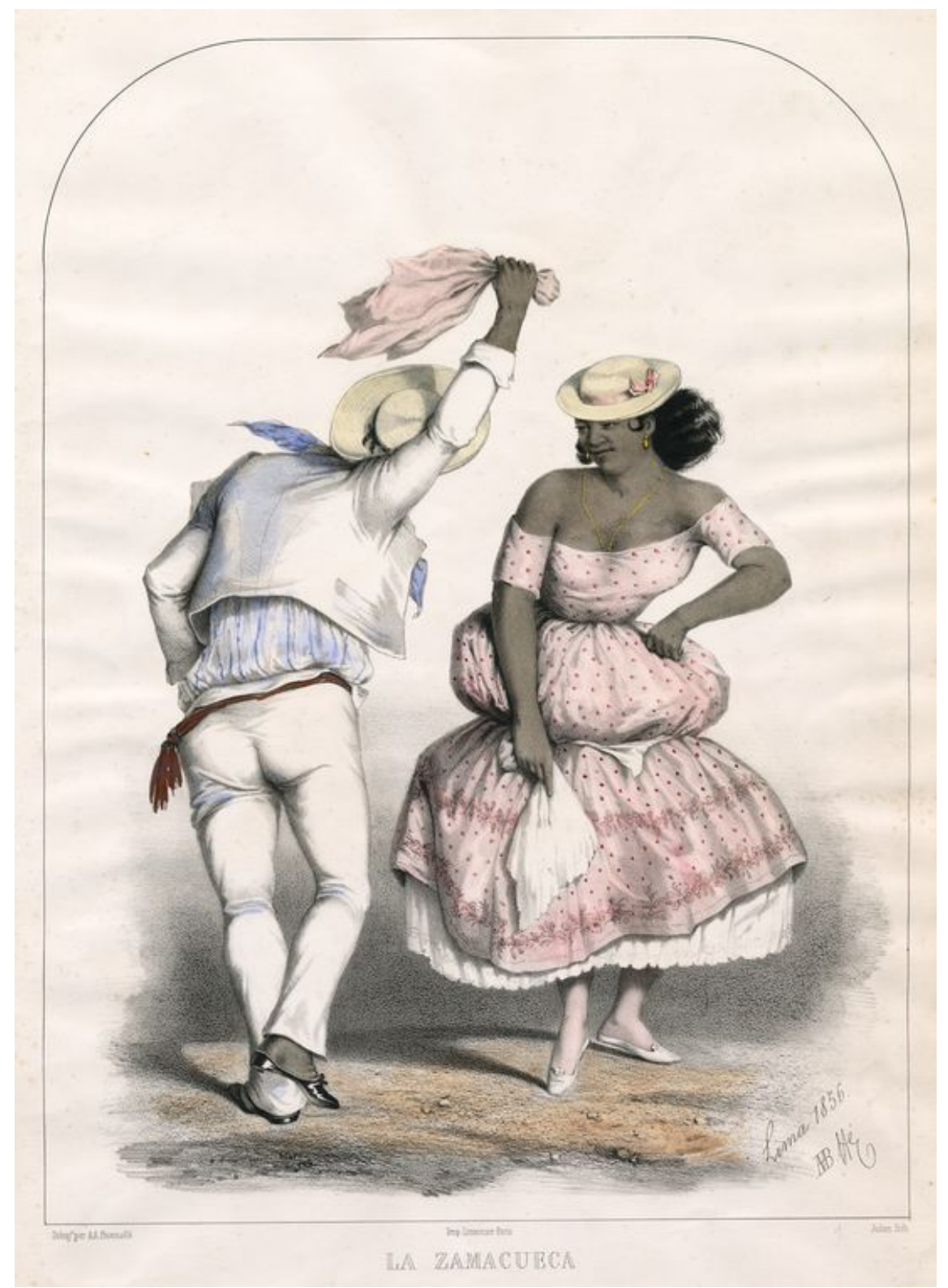

FIGURA 1 La zamacueca.

FONTE: BONNAFFÉ, 1857, s.p.

Numa dessas representações, um casal de negros peruanos dança com seus trajes costumeiros. O homem com seu sombreiro de palha fina, sua jaqueta e seu 
lenço. A mulher com sua blusa e sua saia larga e comprida. Trata-se de uma dança de sedução e fuga. O homem corteja a mulher que resiste às investidas do parceiro de forma lúdica e ambivalente, uma vez que a fuga não é um abandono, mas uma condição para a continuidade do jogo. A repetição dos trajes, dos adereços e dos movimentos nas mais diversas representações ajudam a reforçar as características essenciais ao costume e a transformá-lo em tradição. Nessas pinturas, a zamacueca é uma fórmula e um item de exportação. Os negros americanos que a dançam -- em sua maioria escravizados e descendentes de escravizados -- são apenas um suporte para esta forma. Eles não têm história, não têm personalidade. Não interessa que significado eles dão às suas festas e danças. Interessa apenas o traço exótico, que será exportado para Europa e reproduzido em estampas, alimentando a imaginação do Ocidente. O “exótico" dos álbuns dos pintores viajantes e o "grotesco" do dicionário da Real Academia Espanhola são os dois extremos da máquina discursiva europeia a serviço da submissão de outros continentes. O primeiro agindo no sentindo da despersonalização dos indivíduos, o segundo reagindo contra a potência de suas expressões socioculturais.

Em 1937, Nicanor Parra publica o seu primeiro livro, Cancionero sin nombre, fortemente influenciado por um trabalho de pesquisa dos costumes e tradições camponesas do centro-sul chilenos. O poema "Remolino interior" é o monólogo de um típico caipira caricaturado que canta os seus costumes. No entanto, diferentemente das ilustrações costumbristas do século XIX, o poema de Nicanor Parra não se resume à representação pitoresca de uma expressão cultural. O personagem de "Remolino interior" se mostra um indivíduo complexo e contraditório ao se definir, ao mesmo tempo, um tipo amigável e rústico, delicado e indelicado, como sugerem os dois últimos octossílabos da primeira copla do poema:

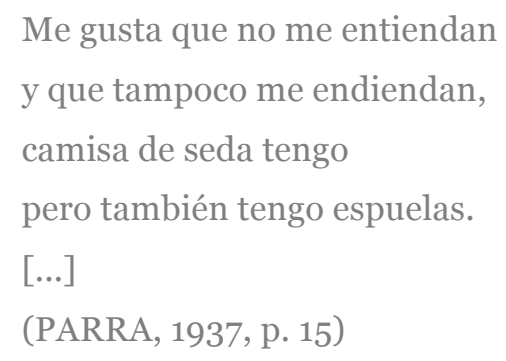


O caráter e o comportamento paradoxais desse personagem se imprimem em seu próprio modo de vestir. A delicadeza da seda contrasta com a rispidez das esporas de montaria. Aqui, a figura típica do camponês trabalhador e festivo, em paz com sua condição existencial, começa a se complexificar. Aqueles que tentam extrair um contorno exótico de seu modo de vida e de seus hábitos culturais encontram um temperamento arredio, um remolino que envolve e confunde, tornando-o incompreensível e inapreensível. Mais do que os seus costumes, o personagem ressalta a sua personalidade, afirmando uma postura e uma formade-vida.

\section{REMOLINO INTERIOR}

Me gusta que no me entiendan

y que tampoco me entiendan,

camisa de seda tengo,

pero también tengo espuelas.

Si digo que yo te quiero

no es cierto lo que dijera,

y acaso no te saludo

no es cierto que te aborrezca.

Cuando recorro la plaza

me gusta que no me entiendan,

pastillas de menta compro

para corretear la pena.

Voy a sentarme a la plaza

de pena, de pena, pena,

y acaso a la plaza llego

la plaza, plaza me alegra.

Si digo que por las piedras

circula una voz de seda,

quiero decir que en el río

me bebo la luna llena. 
Y como quiero que nadie

sepa lo que me interesa

me pongo a amansar potrancas

celestes sobre la arena.

Y como Chile es mi fundo

me gusta seguir la cueca,

con una chaqueta corta

y un pañuelito de menta.

$\mathrm{Al}$ viento lo voy siguiendo

con un chicote de abejas,

el viento, viento se esconde

detrás, detrás de las puertas.

Si vendo a mi negra vendo

todo lo que a mí me queda, pero la vendo y la vendo para que nadie me entienda.

Y acaso quiero que nadie me pida mi yegua yegua, le digo que si es de noche se asusta de las estrellas.

Y acaso es de día claro

se asusta de las espuelas, yo quiero que nadie entonces me entienda ni que me entienda.

Cuando me subo a los árboles es luna mi calavera, me gusta, me gusta, gusta, me gusta que no me entiendan.

Pero hablando en serio serio 
que nadie me niega niega

que cuando subo a caballo

me pongo mis dos espuelas.

(PARRA, 1937, pp. 15-17)

As repetições excessivas de determinadas palavras, o enlace das coplas e das rimas assonantes dão uma circularidade angustiante ao poema, tanto no plano sintático quanto no plano sonoro. O redemoinho interior do personagem ganha forma no poema, assim como o traçado circular dos dançarinos da cueca, suas voltas e meia voltas, dão forma a um estado de espírito agitado e inquieto recuperado no poema de Nicanor Parra e documentado pelo folclorista chileno Ramón Laval em seu livro Contribuición al floklore de Carahue (Chile), de 1916. Segundo uma das fontes do pesquisador, na segunda metade do século XIX, durante a celebração da Cruz, festejo que acontecia no mês de maio, foliões batiam de porta em porta pedindo esmolas, carregando uma cruz de madeira e um lampião com uma vela acesa. O que se conseguia por meio das esmolas servia para armar uma remolienda: "jarana en que se bebe con exceso y se baila cueca al son de arpa y guitarra" (LAVAL, 1916, p. 21).

Aqui é preciso considerar a imagem evocada por Nicanor Parra na construção de seu personagem e pelos brincantes da cueca no século XIX: um redemoinho pode ser um movimento giratório, uma pessoa inquieta, um amontoamento de gente, um distúrbio ou uma alteração no curso normal das coisas, o que significa que a cueca foi compreendida, desde a sua formação, como uma manifestação movida por uma energia caótica e por uma força disruptiva, precisamente aquela contra a qual Espanha reagia em sua primeira definição da zamacueca no dicionário da Real Academina da Língua, precisamente aquela que não se podia entrever nas pinturas costumbristas europeias e precisamente aquela que foi apagada pelo olhar de corte nacionalista e pelas políticas culturais da ditadura de Augusto Pinochet, entre os anos de 1973 e 1989.

Nessa época, havia "una nube de inconsistencia, una censura permanente como arma de defensa del poder dominante, junto a un proceso traumático que sembraba la incertidumbre colectiva" (VILLARROEL e JARA, 2014, p. 153). De um lado, os protocolos do regime militar ditavam e promoviam representações 
estético-políticas cujo objetivo era a construção de símbolos nacionais que expressassem "[...] una cierta 'chilenidad' [...]” (Ibidem, p. 153). De outro lado, artistas como Violeta e Nicanor Parra e ativistas políticos criavam um movimento de difusão do folclore e dos costumes populares como um instrumento de resistência. Esses dois movimentos antagônicos caracterizam o que a historiadora chilena Karen Esther Donoso Fritz denominou "la batalla del folklore" (Ibidem, p. 153).

Uns dos principais atores desse empreendimento político e cultural foi o Conjunto Folclórico da Agrupación de Familiares de Detenidos Desaparecidos (AFDD). As integrantes desse conjunto, mães, filhas e irmãs de presos desaparecidos, se apropriaram da cueca, a "dança nacional", para manifestar sua posição contrária à violência do regime militar. Para isso, foi preciso restituir o elemento disruptivo da cueca. Se a dança havia sido institucionalizada como uma dança romântica que representa o galanteio do homem e as evasivas presunçosas da mulher, uma questão ficava no ar: onde estavam os homens com os quais essas mulheres deviam dançar a cueca, onde estavam as mulheres com que os homens deviam festejar?

Em 8 de março de 1978, durante uma comemoração do Dia Internacional da Mulher realizada no Teatro Caupolicán de Santiago, diversas organizações de mulheres se reuniram, entre elas, o Conjunto Folclórico da AFDD; "este acto constituyó la primera celebración masiva bajo la dictadura del general Pinochet” (Ibidem, p. 139). Perante um teatro lotado, as integrantes do conjunto apresentaram duas canções: "Que pena siente el alma”, de Violeta Parra, e "La cueca sola”, de Gala Torres:

\section{LA CUECA SOLA}

\section{(Brindes)}

Yo brindo por la verdad, la justicia y la razón porque no exista opresión, ni tanta desigualdad. Con coraje y dignidad, de este mal hay que salir, vamos a reconstruir y con cimientos bien firmes para que jamás en chile esto se vuelva a vivir. 
(Cuarteta)

(Mi vida) En un tiempo fui dichosa,

(mi vida) apacibles eram mis días,

(mi vida) más llegó la desventura;

(mi vida) terminó lo que más quería.

(Seguidillas)

Me pregunto constante

¿Dónde te tienen?

Y nadie me responde

y tú no vienes.

Y tu no vienes, mi alma,

larga es la ausencia,

y por toda la tierra

pido clemencia.

(Remate)

Sin ti, prenda querida, triste es la vida.

(TORRES, 1978)

A cueca sola segue a estrutura rígida da cueca tradicional: um brinde para iniciar a dança e ressaltar o seu caráter festivo; um quarteto de redondilhas maiores; uma ou mais seguidillas, estrofe formada por duas redondilhas maiores e duas menores, dispostas em alternância, e um arremate formado por um dístico, sendo o primeiro verso uma redondilha maior e o segundo, uma redondilha menor. Contudo, nessa ocasião, havia dois fatores importantes que diferenciavam o ritual tradicional da cueca e a apresentação do Conjunto Folclórico da Agrupação de Familiares de Presos Desaparecidos. O primeiro diz respeito à letra da canção: uma denúncia direta da violência empregada pelo regime militar contra os seus opositores. O segundo diz respeito à materialização da ausência dos familiares 
desaparecidos, que constitui o tema da canção: em lugar de dançar a cueca em pares formados por um homem e uma mulher, como manda o costume, as integrantes do Conjunto Folclórico dançaram a cueca sozinhas.

Em 8 de março de 1978, uma nova tradição foi inaugurada no Chile. Uma tradição de mulheres que, ao alterar um elemento característico de um costume, redirecionaram o seu valor simbólico em favor de uma luta política. Este fato teve desdobramentos significativos do ponto de vista social. Um deles foi o reposicionamento das mulheres chilenas em sua relação com determinados "bens comuns”, dentre eles a cueca, o espaço público, a participação e o exercício da cidadania. Um novo agente entrava em cena na história da zamacueca para retomar a sua energia política e disruptiva: a mulher. Um agente não menos estereotipado e excluído do que o negro e o índio, mas que deixa o lar e o trabalho doméstico para dançar cueca nos teatros e nas praças, acompanhadas pela ausência de seus familiares.

\section{REFERÊNCIAS}

BONNAFFÉ, A.A. Recuerdos de Lima: album, tipos, trajes y costumbres. Lima: A.A. Bonnaffé, 1957.

GARRIDO, Pablo. Biografía de la cueca. Santiago de Chile: Editorial Nascimento, 1976.

HOBSBAWM, Eric; RANGER, Terence (Orgs.). A invenção das tradições. Rio de Janeiro: Paz e Terra, 1984, pp. 9-23.

LAVAL, Ramón. Contribuición al floklore de Carahue (Chile). Madrid: Lebrería General de Victoriano Suárez, 1916.

PARRA, Nicanor. "Remolino interior". In: Cancionero sin nombre. Santiago de Chile: Editorial Nascimento, 1937.

REAL ACADEMIA ESPAÑOLA. Diccionario de la lengua española, 23. ${ }^{a}$ ed., [versão 23.3 online]. https://dle.rae.es/cueca?m=form [3 de dezembro de 2019].

RIVIALE, Pascal. "Entre lo pintoresco, el costumbrismo y la etnografía: relaciones e influencias recíprocas en las artes gráficas peruanas y francesas en el siglo XIX". In: HISTOIRE(S) de l'Amérique latine, 2011, vol. 6.

TORRES, Gala. “La cueca sola”. In: Conjunto Folclórico de la AFDD. Canto esperanza. Santiago, 1999. 
VILLARROEL, Johan Manuel Ponce; JARA, Michelle Sara Mura. Reconstrución histórica de la cueca sola. Desde el imaginario político y social en Chile (19781990). Santiago: Universidad de Arte y Ciencias Sociales, 2014. 